University of Wollongong

Research Online

Faculty of Business - Papers (Archive)

Faculty of Business and Law

$1-1-2015$

Salespeople's learning by doing and pricing strategy

Qiang Lu

University of Sydney

Ranjit Voola

University of Sydney

Shahriar Akter

University of Wollongong, sakter@uow.edu.au

Follow this and additional works at: https://ro.uow.edu.au/buspapers

Part of the Business Commons

Research Online is the open access institutional repository for the University of Wollongong. For further information contact the UOW Library: research-pubs@uow.edu.au 


\title{
Salespeople's learning by doing and pricing strategy
}

\begin{abstract}
Understanding the salespeople's dynamic learning process is critical in effective sales force management. Particularly, the ability to understand the customer intimately is critical in facilitating sales people develop capabilities that allow them set prices that best meet the needs of the customer and the company objectives. To the best of our knowledge, there are no studies structurally modelling salespeople's learning by doing. We develop a Bayesian learning framework to capture salespeople's learning by doing. In doing so, we argue that for sales organizations who delegate pricing authority to sales people, it is imperative that they understanding how their sales people learn by doing. Our framework allows us to estimate; 1 ) salespeople's learning from successful and failed cases separately; and 2) salespeople's prior skills, (i.e. their skills when they first join the firm) and potential skills (i.e. the ultimate skills that salespeople potentially can reach through learning by doing). We illustrate our approach by analysing historical transaction data of a large multinational software company. We argue that understanding of sales people learn by doing is critical in understanding customer facing strategies including pricing.
\end{abstract}

Keywords

strategy, salespeople, pricing, learning, doing

Disciplines

Business

Publication Details

Lu, Q., Voola, R. \& Akter, S. (2015). Salespeople's learning by doing and pricing strategy. In A. Hinterhuber \& S. Liozu (Eds.), Pricing and the Sales Force (pp. 59-74). Abingdon: Routledge.

This book chapter is available at Research Online: https://ro.uow.edu.au/buspapers/867 


\title{
Salespeople's Learning by Doing and Pricing Strategy
}

\begin{abstract}
Understanding the salespeople's dynamic learning process is critical in effective sales force management. Particularly, the ability to understand the customer intimately is critical in facilitating sales people develop capabilities that allow them set prices that best meet the needs of the customer and the company objectives. To the best of our knowledge, there are no studies structurally modelling salespeople's learning by doing. We develop a Bayesian learning framework to capture salespeople's learning by doing. In doing so, we argue that for sales organizations who delegate pricing authority to sales people, it is imperative that they understanding how their sales people learn by doing. Our framework allows us to estimate; 1) salespeople's learning from successful and failed cases separately; and 2) salespeople's prior skills, (i.e. their skills when they first join the firm) and potential skills (i.e. the ultimate skills that salespeople potentially can reach through learning by doing). We illustrate our approach by analysing historical transaction data of a large multinational software company. We argue that understanding of sales people learn by doing is critical in understanding customer facing strategies including pricing.
\end{abstract}

Key Words: Salespeople Learning, Pricing, Learning by Doing, Bayesian Learning Model 


\section{INTRODUCTION}

Getting the price right is the quickest and most robust way for a company to realize maximum profit by increasing sales (Marn \& Rosiello, 1992). Delegation of pricing authority to salespeople has been an important research area in sales management (Stephenson, Cron \& Frazier, 1979; Misra \& Prasad, 2004: Homburg, Jenson \& Hahn, 2012). The critical question now is, 'who should control pricing strategies'? the organization or the sales people. According to Homburg et al., (2012, p. 50) pricing authority in the context of salespeople refers to "the extent to which local salespeople are independent from central sales management in their pricing decisions during negotiations with customers". In summarizing previous research on pricing delegation, Joseph (2001) argues that if the sales force is based on gross margins (as opposed to sales), then the sales person's intimate understanding of the customers' perceptions of the organization suggests that delegating pricing to the salesperson will result in greater profitability. In other words, as the salespeople are the eyes and ears of the organization, they are best positioned to understand customers and customize profitability pricing strategies (Dolan \& Simon, 1996).

Thus, the dynamics of price getting or converting the list prices into actually realized prices are largely determined by salesforce characteristics (e.g. Sujan, Sujan \& Bettman 1988; Leong, Busch \& John, 1989; McFarland, Challagalla \& Shervani, 2006; Franke \& Park, 2006). Getting the price right by salesforce is one of the building blocks of marketing performance as it directly affects the financial performance of the company (Marn \& Rosiello, 1992).

As contemporary firms conduct business in a dynamic environment (Turley \& Geiger, 2006), the strategic importance of price getting rather than price setting by salesforce is gaining increased attention, including such methods as adaptive selling (McFarland et al., 2006, Franke \& Park, 2006). Therefore, examining how salespeople learn to set prices is a 
critical aspect in understanding salespeople's effectiveness. Essentially, salespeople learn when they process new information and change behavior (Chonko et al., 2003; Huber, 1991). Crucially, as they are at the frontline of an organization and they are the implementers of the firm strategy (Crosby et al., 1990), they are best positioned to aid change (Weitz et al., 2001). It also emphasizes the domain of adaptive selling, "the altering of sales behaviors during a customer interaction or across customer interactions based on perceived information about the nature of the selling situation" (Weitz, Sujan \& Sujan, 1986, p. 175), in order to enable salespeople to tailor pricing to fit individual customers' needs and preferences.

According to Franke and Park (2006), the benefits of price getting can outweigh the costs of information gathering, specifically when salesforces are equipped with better resources, higher possibility of having large order in complex buying situation and less chances of conflict in continuing customer relationships. The extant literature also emphasizes adaptive selling in price getting by simple adjustments in answering questions and comments, which improve sales performance across situations (e.g., Boorom, Goolsby \& Ramsey 1998; Spiro \& Weitz 1990; Weitz, Sujan \& Sujan 1986).

The contention of this chapter is that the best way to learn about customers, particularly in the $\mathrm{B} 2 \mathrm{~B}$ context is to learn by doing. Therefore, the more interactions a sales person has with a client, the more likely over time that they intimately understand the customer and develop sales capabilities that allow them to design an optimal pricing strategy. However, the fundamental process of how sales person learn by doing has not been critically examined in the sales literature. (e.g. Sujan, Weitz \& Kumar, 1994; Kohli, Shervani \& Challagalla, 1998; Wang \& Netemeyer, 2002). Studies that have examined learning are primarily survey-based. To this end, based on Erdem and Keane's (1996) Bayesian learning model, we develop a salespeople learning model to estimate salespeople's learning by doing. Our structural model captures how salespeople use experience to update their skills. We adopt a Hierarchical 
Bayesian model to estimate individual salesperson level parameters. To our knowledge, this is the first study which investigates price getting by exploring salespeople's learning by doing behaviour. Our structural model provides deeper insights into salespeople's learning and its effectiveness than a reduced-form model. This in turn allows us develop generic process of learning by doing, which we argue is critical to understand if firms want to develop sales people capabilities in understanding their customers, and then developing customized strategies including pricing strategies.

\section{Learning}

Learning has become an important construct in marketing due to its effects on a firm's competitive advantage (Hurley \& Hult, 1998). In the context of salespeople, Sujan, Weitz and Kumar (1994) highlight that there are two goal orientations: learning and performance, where salespeople adopting a learning orientation "enjoy the process of discovering how to sell effectively. They are attracted by challenging situations and not unduly bothered by mistakes. They value the feelings of personal growth and mastery they derive from their job" (p. 39). A salesperson's learning orientation has been empirically linked to adaptive selling, work effort, and performance (Kohli et al., 1998; Sujan et al., 1994) and self-efficacy (Wang \& Netemeyer, 2002). On the other hand, a performance orientation is characterised by "a focus on performing well because they see good performance as a means to obtaining extrinsic rewards....(and) are concerned with being judged able and showing evidence of ability by being successful” (Kohli, Tasadduq \& Challagalla, 1998, p. 263). In the context of a learning orientation, there are several mechanisms by which salespeople learn. Two basic modes of learning have been suggested a) vicarious learning, or learning through observation, comparison and modelling (Weiss, 1990) and b) enactive learning or learning through direct experience. In the context of the sales force, vicarious learning has been linked to cognitive 
selling scripts (i.e. mental representation of a sales approach [Leigh, 1987]; see Table 2 for a types of sales people training). Sales force training is a representation of vicarious learning (Cron et al., 2005). This study emphasises the latter: enactive learning, which has not been explored in-depth.

\section{Salespeople's Skills}

Through learning, a salesperson acquires the required mechanisms and skills for developing and executing effective courses of action to manage various demands (Wang \& Netemeyer, 2002), such as developing a pricing strategy. Consequently, through learning they build their skills and coping abilities which then serve as a foundation for the subsequent individual salesperson's outcomes (see Table 2 for a summary of sales skills) and influence a firm's effectiveness broadly and specific marketing strategies. Weitz and Bradford (1999), in arguing the changing nature of selling, highlight various skills that would be required for a $21^{\text {st }}$ century salesperson. For example, the salesperson must have sophisticated knowledge of the buying firm (including high levels of information acquisition skills, problem solving skills, and innovativeness). Other researchers have highlighted time management, and the ethical and leadership skills of the salespeople. Furthermore, a salesperson's skill level can include the extent of horizontal and vertical dimensionality including a salesperson's ability to cope with variations across sales situations and skill in coping with variation within a sales situation (Leong, Busch \& John, 1989).

Salespeople's skills have been defined variously, for example, Pettijohn, Pettijohn and Taylor (2002, p. 747) define them as the "capabilities regarding his or her sales presentation, need identification, suggestive selling, product knowledge, time allocations and orientation towards assisting the customer." This suggests that tasks including customer oriented selling may not be feasible for the unskilled salesperson. Furthermore, Leong et al. (1989) define it 
as the capability of an individual to effectively implement all the tasks involved in a sale. As the data set in this paper is particular to a multinational software company, salespeople's skills in this context could include: customer orientation or the ability to identify the customer needs and preferences, ability to adopt adaptive selling, knowledge of the software and the ability to exhibit horizontal and vertical dimensionality.

A salesperson's performance could be influenced not only by his/her skill but by his/her effort (Brown \& Peterson, 1994; Manchanda \& Chintagunta, 2004). Brown and Peterson (1994 p. 71) define effort as "the force, energy or activity by which work is accomplished." We argue that even if a salesperson has a high level of skill, but that salesperson does not expend the required effort, then he/she may not achieve the required performance. Therefore, we argue that skill by itself may not lead to client satisfaction; it must be augmented by the effort of the salesperson. Salesperson's effort may be influenced by various factors including the fit (match) of the salesperson to the job. In our framework, a salesperson's skill is the "match" skill which includes both the salesperson's "basic" skill and the effort of the salesperson. Thus, salespeople learn about their "match" skills through experience, which implies, besides pure "basic" skills, they learn about their fit with the job to decide how much effort to put into the tasks. The "match" skill represents the match between the job and the salesperson. A salesperson may be able to reach a certain skill, but he/she may not be willing to expend the appropriate level of effort to implement the skill because he/she does not like the job nature that much ${ }^{1}$.

Figure 1 outlines the salespeople learning process. The first part of the figure (i.e. boxed) suggests that each salesperson has a basic skill, prior to joining the job (e.g. due to prior education or prior experience in a similar industry). When a salesperson joins the firm he/she has certain expectations and beliefs about the job nature, characteristics, and how close

\footnotetext{
${ }^{1}$ In the remainder of the paper, we use skills and "match" skills interchangeably.
} 
these beliefs are to their desired ones. These beliefs are labelled in this paper as 'perceived job match'. Perceived job match can be influenced by several variables, e.g. role conflict and role ambiguity (Brown \& Stevens, 1993, 1994). For example, if the salesperson feels that 1) the perceived role behavior is different to their internal values and standards or desired responsibilities/duties (i.e., role conflict) and; 2) the behavioural requirements of the job are not clear to him/her (i.e., role ambiguity), his/her perceived job match is lower. This lower perceived job match is argued to reduce the effort he/she applies to implement the basic skill required in the selling. This implemented skill is termed as the prior "match" skill. The second part of the model illustrates that he/she can update his/her "match" skill by learning through successful sales and failed sales. Figure 1 also highlights that several demographic aspects of the salespeople influence how fast they learn from failure and success. This learning by doing process eventually leads to the potential "match" skill, which is the ultimate implemented skill level the salesperson can obtain.

\section{Contributions}

Learning by doing is an important mechanism by which salespeople learn (Wang \& Netemeyer, 2002); however, researchers have not examined this phenomenon structurally. In structural modelling and game theory, researchers have emphasised sales force compensation and sales contests (Lal, 1986; Lal \& Staelin, 1986; Lal \& Srinivasan, 1993; Kalra \& Shi, 2001; Kalra et al., 2003; Krafft, Albers \& Lal, 2004), and optimal staffing levels (Misra et al., 2004). In the context of learning, structural modelling researchers have applied the Bayesian Learning Model to investigate consumer learning relating to product quality (Erdem \& Keane, 1996; Iyenger, Ansari \& Gupta, 2007), and physician learning about new drugs (Crawford \& Shum, 2005; Ching, 2007; Narayanan \& Manchanda, 2007). These studies find that learning about product quality from consumer experiences is an important element in the consumer 
decision-making process. Based on the Consumer Bayesian Learning Models (Erdem \& Keane, 1996), we develop a structural salespeople learning framework. This is, to the authors' knowledge, the first paper to structurally model salespeople's learning by doing (i.e. learning from success and learning from failure), which provides a novel approach to research in salespeople's learning.

Kohli et al. (1998) argue that understanding individual member learning is critical as firms learn through their individual members. Our framework uses a Hierarchical Bayesian Model to capture individual salesperson parameters. This model allows managers to develop effective sales force management strategies; including monitoring the improvements in learning and the effects of these improvements, sales force retention and optimal task allocations. This framework also investigates how certain demographics of individual salespeople influence their performance (Churchill, Ford, Hartley \& Walker, 1985).

Broadly, sales force literature has emphasised two goal orientations; learning and performance orientations (Kohli et al., 1998; Sujan et al., 1994). This study fits within this discourse and by structurally examining learning from success and learning from failure; it contributes to an in-depth understanding of salespeople's learning orientation. To this end, we model the individual salesperson's learning by doing within a Hierarchical Bayesian Learning Framework. We apply the model to the individual salesperson level data from a large multinational software firm. The remainder of the paper is organized as follows: We develop a Hierarchical Bayesian Model after introducing our basic model. Then, we provide a discussion of identification and explain the data and results. Finally, we discuss some managerial implications, followed by the conclusion. 


\section{THE MODEL}

Consider a general Business-to-Business market in which a client decides which alternative to buy among $\mathrm{J}$ alternatives. In the Business-to-Business market, salespeople play an essential role in a client's decision-making process. An effective salesperson understands a client and provides the information or service that a client really wants. We assume a client's utility of choosing product $\mathrm{j}$ can be represented by the following:

$$
u_{p j t}=\omega_{p j} M_{p j t}+\beta_{p} X_{p j t}+e_{p j t}
$$

where $u_{p j t}$ is the utility of a typical client buying product $\mathrm{j}$ from salesperson $\mathrm{p}$ at time $\mathrm{t}$. As salespeople play an important role in the process, this utility is at the individual salesperson level. $M_{p j t}$ are a vector of the salesperson p's skill specific variables. $X_{p j t}$ are a vector of the case specific explanatory variables such as client sizes, open days, and case sizes. We assume $e_{i j g}$ is Type I extreme value distributed, so that the client's choice problem can be transformed into a simple logit model. The individual salesperson level data makes the identification of our individual level logit model possible.

It should be noted that Equation (1) can only be used for the alternatives under consideration. The client utility from purchasing an "outside" good is represented by Erdem and Keane (1996) and Nevo (2001) as:

$$
u_{p 0 t}=\beta_{p 0} X_{p 0 t}+e_{p 0 t} .
$$

In this paper, we use the data from a large multinational software company to illustrate our framework. This company sells its products mainly to business users. Salespeople need to learn about the product and service, job characteristics and selling skills required to be successful, among other issues. Most companies provide orientation training for new salespeople and ongoing training for existing salespeople. Although training is an important 
mechanism for learning, learning by doing is also critical. In this study, we focus on this second type of learning: learning through experience.

Salespeople joining a new company need to learn through experience, including those who have had previous selling experience. Previous experience of the salespeople is useful, but they still need to learn new skills in order to succeed in the new company. Furthermore, salespeople also need to learn about the job nature and characteristics. We capture this learning process from historical transaction data through the Bayesian learning method.

As a salesperson's performance influences consumer purchase decision, how a salesperson handles a sale is very important. This is related to a salesperson's "match" skill. The salesperson can update his/her "match" selling skill by learning through experience. The salesperson can learn from a case he/she handles successfully. Thus, each such handling of a case can provide the salesperson with a signal about the ideal method to handle the sale (Erdem and Keane 1996; Ching 2007; Narayanan and Manchanda 2007). Therefore, the salesperson updates his/her match skill from success as follows:

$$
S_{p j t} \sim N\left(K_{p j}, \sigma_{S_{p}}^{2}\right)
$$

$S_{i j t}$ is the signal salesperson $\mathrm{p}$ gets from selling product $\mathrm{j}$ successfully at time $\mathrm{t}$. It is assumed to be normally distributed. The mean $K_{i j}$ is the potential "match" skill that salesperson $\mathrm{p}$ should have while selling product $\mathrm{j}$. The salesperson can also learn from failed cases. We expect that the learning from successful cases is different from the learning form failed cases although both can provide a signal to the salesperson about his/her true match skill. Therefore, the salesperson updates his/her match skill from failure as follows:

$$
F_{p j t} \sim N\left(K_{p j}, \sigma_{F_{p}}^{2}\right)
$$


$F_{p j t}$ is the signal salesperson $\mathrm{p}$ gets from selling product $\mathrm{j}$ unsuccessfully at time $\mathrm{t}$. It is also normally distributed with mean $K_{p j}$, and variance $\sigma_{F_{p}}^{2}$. So both $S_{p j t}$ and $F_{p j t}$ can signal the salesperson's potential "match" skill $K_{p j}$ at different rates, $\sigma_{S_{p}}^{2}$ and $\sigma_{F_{p}}^{2}$, respectively.

Here, we define $M_{p j t}=E K_{p j t} . E K_{p j t}$ is what the salesperson $\mathrm{p}$ believes he/she should do given the information he/she has at time t. Thus, it represents the mean service level a client obtains from the salesperson $\mathrm{p}$ at time t. According to the Bayesian rule (DeGroot 2004), tt evolves as follows:

$$
E K_{p j t}=E K_{p j t}+D_{S p j t} \gamma_{p j t}^{S}\left(S_{p j t}-E K_{p j t}\right)+D_{F p j t} \gamma_{p j t}^{F}\left(F_{p j t}-E K_{p j t}\right)
$$

where,

$$
\begin{aligned}
& \gamma_{p j t}^{S}=\frac{\sigma_{K p j}^{2}(t-1)}{\sigma_{K p j}^{2}(t-1)+\sigma_{S_{p}}^{2}}, \\
& \gamma_{p j t}^{F}=\frac{\sigma_{K p j}^{2}(t-1)}{\sigma_{K p j}^{2}(t-1)+\sigma_{F_{p}}^{2}} .
\end{aligned}
$$

$D_{S p j t}$ and $D_{F p j t}$ are dummy variables for successful and failed cases handled by the salesperson $\mathrm{p}$ respectively. Besides the mean belief, $\sigma_{K p j}^{2}(t)$ is the salesperson $\mathrm{p}$ 's belief variance at time t. It essentially shows how confident he/she feels in doing what he/she believes. Overtime, a salesperson will converge to his/her potential "match" skill level with more confidence. According to DeGroot (2004) the variance evolves as follows:

$$
\sigma_{K p j}^{2}(t)=\frac{1}{\frac{1}{\sigma_{K p j}^{2}(t-1)}+\frac{D_{S p j t}}{\sigma_{S_{p}}^{2}}+\frac{D_{F p j t}}{\sigma_{F_{p}}^{2}}} .
$$

\section{DATA AND ESTIMATION RESULTS}

Data Description 
We use data from a large multinational software company for the period June 2003 to June 2006. This company mainly sells its products to business users in North America. The task of the salespeople is to sell to their potential customers from potential customer lists. These lists are obtained from several sources (e.g. purchased from information vendors).

The data set includes detailed information about the software of interest, customer name, budget available, status of sales lead (i.e. open, won and lost), the time when the case was opened and closed, potential competitors, and the purchase amount. It also indicates whether there was strong competition. The data is at the individual salesperson level and therefore it identifies the specific salesperson that handles the case. In our analysis, we only deal with the cases that have been closed (i.e. won or lost).

We also obtained the salespeople's average salary and demographic information based on the manager's evaluation. As some of the salespeople have already left the company, the salary used is the average salary during the period. The demographic information obtained includes: gender, age, marriage status, and education.

\section{Results}

Tables 3 presents the main results of our model. Next, we discuss the results in detail.

Mean level parameters. The mean level parameters are reported in Table 3 . The first column (Intercept) shows the mean values of the parameters across salespeople with different salaries and demographics. The prior "match" skill $(-0.02)$ is much smaller than the potential "match" skill level (0.65) salespeople can reach. This suggests that in general salespeople improve their selling skill through experience. Here we need to clarify that the potential skills can be higher or lower than the prior skill levels as the skill in our framework is the "match" skill, which represents the match between the job and the specific salesperson. We explore this further in the section discussing heterogeneity. 
Interestingly, salespeople can learn more from failed cases than from successful cases as the variance for learning from successful cases (5.48) is much bigger than the variance for learning from failed cases (3.52). This can explain why many firms in the industry encourage their employees to engage in innovative activities freely without risk. Furthermore, this can be due to the increase in the adoption of a learning orientation in salespeople. One of the key characteristics of a learning orientation is that salespeople are not bothered by failure and in fact see it as a way to master their job (Sujan et al. 1994).

The results suggest that the clients give a positive utility weight $(0.15)$ to the salespeople's skills, showing that on average, clients enjoy good service from the salespeople. Client ranking is a dummy variable where 1 denotes a Fortune 1000 company. The coefficient for Client Ranking (0.29) shows that the company of interest is good at handling large businesses, whilst it is not performing very well in the context of smaller businesses. This finding was corroborated by the firm. Case open days denotes the days from the time when the opportunity opened to the time when it was closed. Case open period has a negative impact on outcome (-10.02). This is because clients are more likely to purchase at an earlier period if they decide to buy, therefore, the longer the case is open, the less likely it is that the purchase will happen. Case size denotes the monetary value of a case. The findings show that the firm does not do very well with large cases as the coefficient for case size is $(-0.41)$.

Major competitor denotes the two major competitors in the industry. The result $(-0.35)$ suggests that the company is doing well while competing with big players. The variable competition refers to the competition information provided by salespeople. This variable is different from the variable major competitor as this competition was not necessarily coming from the two main competitors. The result shows that competition does influence salespeople's performance (4.51). 
Salary and demographics. Table 3 also includes the impact of salespeople's salary and demographics on specific parameters. The second column shows the influence of salary on the parameters. Salespeople who have higher salaries have relatively higher prior "match" skill levels, but lower potential "match" skill levels. This suggests that the firm compensates salespeople based on the prior skills but not on the potential skills. It can be argued that this is not a good strategy as the firm is not compensating the "right" salespeople appropriately. This could be one of the reasons for the high turnover rate in the firm. Furthermore, salespeople with higher salaries learn faster as the salary has a negative impact on learning variance.

The third column shows the influence of gender. Men are more likely to learn through experience, while women are effective in handling competitive cases. The next column shows that young salespeople can learn fast while senior people can do well when strong competition exists. The last column shows that salespeople with a postgraduate degree can learn fast from success, but not failure, and have better prior and potential skills compared with salespeople who do not have a postgraduate degree. The result also shows better educated salespeople can handle competition better.

The estimate for a specific demographic profile is measured by the sum of the interaction parameter weighted salary and demographics. For example, the potential match skill for a single male salesperson with average salary and age is the sum of the interaction parameters $(0.65,-0.13,-0.52,0.56,0.27$, and 1.00) weighted respective personal information $^{2}$. Overall, the interaction between salespeople performance and personal specifics (i.e. salary and demographics) can provide managers with a lot of useful information.

\footnotetext{
2 The salary and demographics have been demeaned in the estimation.
} 


\section{CONCLUSION}

Sales force management, and in particular salespeople learning, is a critical issue that requires scholarly attention, particularly in facilitating customized pricing strategy. The findings of the study provide empirical generalizations about learning by doing in getting the right prices in the context of sales force research. The findings indicate that adaptive salespeople are likely to outperform their colleagues in realizing maximum sales and profit. In this paper, we develop a Bayesian learning model to explore learning by doing in getting the price right. To our knowledge, this is the first study to use a structural Bayesian Learning model to investigate salespeople's learning through experience in understanding the customer and developing optimal pricing strategy using data from a large multinational software company. This model reflect that learning by doing is less monotonous than repeating the same message, which focuses more on interaction with prospects.

Our structural model contributes to the sales force management literature in several ways. First, we provide a mechanism for monitoring salespeople's learning through experience from their historical records in getting the price. This would reduce the costs of obtaining further information to estimate salesperson learning. Second, we estimate the individual salesperson level parameters. This provides managers with detailed information that can be used for better managing the sales force than aggregate level parameters. For instance, we can identify a salesperson's potential "match" skill, which represents his/her match with the job. Third, we investigate the impact of demographics. This provides managers with useful information in relation to the recruitment of salespeople.

The results from the large software company data suggest that: 1) learning by doing plays an important role in price adjustments and improving a salesperson's performance; 2) on average, salespeople learn more from failure than success cases in getting the price; 3) 
heterogeneity in salespeople learning exists; 4) salespeople's salary, age, gender, marriage status and education can influence salespeople learning and developing optimal pricing strategies. These findings have clear implications for sales force management in terms of job allocation and in providing an environment where learning is encouraged in setting customized pricing.

Overall, the findings indicate that salesforce act more as knowledge brokers, which require them to equip with adequate cognitive abilities in order to tailor prices according to customers' needs. Future research could focus on such behaviour based sales management approaches using experimental and team perspectives in different cultures. These approaches clearly reflect learning by doing in getting the prices, which is aligned with the current paradigm shift from transaction based marketing to relationship focused marketing.

\section{REFERENCES}

Bergen, M., Dutta, S., Ritson, M., \& Zbaracki, M. (2002). Pricing as a strategic capability. Sloan Management Review, 43(3), 61-66.

Bolton, R. N., \& Shankar, V. (2003). An empirically derived taxonomy of retailer pricing and promotion strategies. Journal of Retailing, 79(4), 213-224.

Boorom, Michael L., Jerry R. Goolsby, and Rosemary P. Ramsey (1998), "Relational Communication Traits and Their Effect on Adaptiveness and Sales Performance," Journal of the Academy of Marketing Science, 26 (Winter), 16-30.

Brown, Steven P., \& Peterson, R. A. (1993). Antecedents and consequences of salesperson job satisfaction: meta-analysis and assessment of causal effects. Journal of Marketing Research, 30 (February), 63-77.

— \& Peterson, R. A. (1994). The effect of effort on sales performance and job satisfaction. Journal of Marketing, 58, 70-80. 
Chandrasekaran, M., McNeilly, K., Russ, F. A., \& Detelina Marinova (2000). From uncertain intentions to actual behavior: a threshold model of whether and when salespeople quit. Journal of Marketing Research, 37 (4), 463 -479.

Chen, F. (2005). Sales force incentives, market information, and production/inventory planning. Management Science, 51 (1), 60-75.

Ching, A. T. (2007). Consumer learning and heterogeneity: dynamics of demand for prescription drugs. working paper, University of Toronto.

Chonko, L. B., Dubinsky, A. J., Jones, E., \& Roberts, J. A. (2003). Organizational and individual learning in the sales force: an agenda for sales research. Journal of Business Research, 56, 935-946.

Churchill G.A., Ford, N. M., Hartley, S. W., \& Walker, O. C. (1985). The Determinants of Salesperson Performance: A Meta-analysis. Journal of Marketing Research, 22 (2), 103-118.

Crawford, G., \& Shum, M. (2005). Uncertainty and learning in pharmaceutical demand. Econometrica, 73 (4), 1137-1173.

Cron, W.L., Slocum, J.W., Walle V. D., \& Fu, Q. (2005). The Role of Goal Orientation on Negative Emotions and Goal Setting When Initial Performance Falls Short of One's Performance Goal. Human Performance, 18, 55-81.

Crosby, L. A., Evans, K. R., \& Cowles, D. (1990). Relationship quality in services selling: an interpersonal influence perspective. Journal of Marketing, 54, (July), 68-81.

DeGroot, M. H. (2004), Optimal Statistical Decisions, Hoboken, New Jersey: John Wiley \& Sons.

Dolan, R., \& Simon, H. (1996). Power Pricing! New York: The Free Press.

Draganska, M., \& Jain, D. C. (2006). Consumer preferences and product-line pricing strategies: An empirical analysis. Marketing science, 25(2), 164-174.

Dutta, S., Zbaracki, M. J., \& Bergen, M. (2003). Pricing process as a capability: A resourcebased perspective. Strategic management journal, 24(7), 615-630.

Erdem, T., \& Keane, M (1996). Decision-making under uncertainty: capturing dynamic brand choice processes in turbulent consumer goods markets. Marketing Science, 15 (1), 1-20.

Erffmeyer, R., \& Johnson, D. (1997). The future of sales training: Making choices among six distance education methods. Journal of Business \& Industrial Marketing, 12(3/4), 185-196.

Finn, W. (1984, July). Keep your eye on the sales training manager. Training and Development Journal, 65-67.

Ford, N. M., Walker, O. C., Jr., Churchill, G. A., \& Hartley, S. W. (1987). Selecting successful salespeople: A meta-analysis of 
biographical and psychological selection criteria. In M. J. Houston (Ed.), Review of marketing. Chicago: American Marketing

Association.

Franke, G. R., \& Park, J. E. (2006). Salesperson adaptive selling behavior and customer orientation: a meta-analysis. Journal of Marketing Research, 43(4), 693-702.

Frenzen, H., Hansen, A. K., Krafft, M., Mantrala, M. K., \& Schmidt, S. (2010). Delegation of pricing authority to the sales force: An agency-theoretic perspective of its determinants and impact on performance. International Journal of Research in Marketing, 27(1), 58-68.

Futrell, Charles M., \& Parasuraman, A. (1984). The relationship of satisfaction and performance to sales force turnover. Journal of Marketing, 48 (Fall), 33-40.

Hinterhuber, A. (2008). Customer value-based pricing strategies: why companies resist. Journal of business strategy, 29(4), 41-50.

Homburg, C, Jensen, O., \& Hahn, A. (2012). How to organize pricing? Vertical delegation and horizontal dispersion of pricing authority. Journal of Marketing 76:5, 49-69

Honeycutt, E., Ford, J., \& Tanner, J. (1994). Who trains salespeople? Industrial Marketing Management, 23, 65-70.

Honeycutt, E., McCarty, T., \& Howe, V. (1993, Winter). Sales technology applications: Selfpaced video enhanced training: A case study. Journal of Personal Selling \& Sales Management, 13(1), 73-79.

Honeycutt, E., Ford, J., Lupton, R., \& Flaherty, T. (1999). Selecting and training the international sales force. Industrial Marketing Management, 28, 627-635.

Hurley, R.F., \& Hult, T.M. (1998). Innovation, market orientation, and organizational learning: an integration and empirical examination. Journal of Marketing, 62 (3), 42-54.

Inkpen A.C, \& Crossan, M. M. (1995). Seeing is believing: joint ventures and learning organizations. Journal of Management Studies, 32 (September), 595-618.

Iyengar, R., Ansari, A., \& Gupta, S. (2007). A model of consumer learning for service quality and usage. Journal of Marketing Research, XLIV, (November), 529-544.

Joseph, K. (2001). On the optimality of delegating pricingauthority to the sales force. $J$. Marketing 65(January) 62-70.

Kalra, A. \& Shi, M. (2001). Designing optimal sales contests: a theoretical perspective. Marketing Science, 20 (2), 17-193.

Kaminski, P., \& Clark, G. (1987). The readability of sales training manuals. Industrial Marketing Management, 16, 179-184.

- Shi, M., \& Srinivasan, K. (2003). Sales force compensation scheme and consumer inferences. Management Science, 49 (5), 655-662. 
Kohli, A., Tasadduq, K.,Shervani, A., \& Challagalla, G. N. (1998). Learning and performance orientation of salespeople: the role of supervisors. Journal of Marketing Research, 36 (2), 263-274.

Kotler, P. (2011). Reinventing marketing to manage the environmental imperative. Journal of Marketing, 75(4), 132-135.

Lal, R. (1986). Delegating pricing responsibility to the salesforce. Marketing Science, 5(2), $159-168$

Lal, R., \& Staelin, R. (1986). Salesforce compensation plans in environments with asymmetric information. Marketing Science, 5(3), 179-198.

Lal, R., \& Srinivasan, V. (1993). Compensation plans for single- and multi-product salesforces: an application of the holmstrom-milgrom model. Management Science, 39(7), $777-793$

Leach, M., Liu, A., \& Johnston,W. (2005, Summer). The role of self-regulation training in developing the motivation management capabilities of salespeople. Journal of Personal Selling \& Sales Management, 25(3), 269-281.

Leigh, T.W. (1987). Cognitive selling scripts and sales training. Journal of Personal Selling and Sales Management, 7, 39-48.

Leong, S. M., Busch, P. S., \& John, D. R. (1989). Knowledge bases and salesperson effectiveness: a script-theoretic analysis. Journal of Marketing Research, 26, 164-178.

Maglaras, C., \& Meissner, J. (2006). Dynamic pricing strategies for multiproduct revenue management problems. Manufacturing \& Service Operations Management, 8(2), 136-148.

Manchanda, P. \& Chintagunta, P. (2004). Responsiveness of physician prescription behavior to salesforce effort: an individual level analysis. Marketing Letters, 2004, 15:2-3, 129-145.

March, J. G (1991). Exploration and exploitation in organizational learning. Organization Science, 2 (1), 71-87.

Marn, M. V., \& Rosiello, R. L. (1992). Managing price, gaining profit. Harvard Business Review, 70(5), 84-94.

Martin, W., \& Collins, B. (1991, Summer). Sales technology applications: Interactive video technology in sales training: A case study. Journal of Personal Selling \& Sales Management, 11(3), 61-66.

McFarland, Richard. G., G.N. Tasadduq A. Shervani and Goutam N. Challagalla (2006), "Influence Tactics for Effective Adaptive Selling," Journal of Marketing, 70 (4), 103-117.

Misra, S., Pinker, E.J., \& Shumsky, R.A (2004). Sales force design with experience-based learning. IIE Transactions, 36, 941-952. 
Misra, S. (2007). Who's to blame a bayesian decomposition of efficiency in hierarchical sales organizations. working paper, University of Rochester

Misra, B. K., \& Prasad, A. (2004). Centralized pricing versus delegating pricing to the salesforce under information asymmetry. Marketing Sci. 23(1) 21-28.

Montgomery, A. L. (1997). Creating micro-marketing pricing strategies using supermarket scanner data. Marketing Science, 16(4), 315-337.

Narayanan, S., \& Manchanda, P. (2007). Heterogeneous learning and the targeting of marketing communication of new products. working paper, Stanford University.

Pettijohn, C.E., Pettijohn, L.S., \& Taylor, A J. (2002). The influence of salesperson skill, motivation, and training on the practice of customer-oriented selling. Psychology and Marketing, 19 (9), 743-57.

Popescu, I., \& Wu, Y. (2007). Dynamic pricing strategies with reference effects.Operations Research, 55(3), 413-429.

Ricks, Joe, M., Williams, J. A., \& Weeks, W. A. (2007). Sales trainer roles, competencies, skills, and behaviors: a case study. Industrial Marketing Management, Forthcoming.

Ricks Jr, J. M., Williams, J. A., \& Weeks, W. A. (2008). Sales trainer roles, competencies, skills, and behaviors: A case study. Industrial Marketing Management, 37(5), 593-609.

Robinson, L. (1987, May-June). Role playing as a sales training tool. Harvard Business Review, 34-35.

Rollins, M., Nickell, D., \& Wei, J. (2014). Understanding salespeople's learning experiences through blogging: A social learning approach. Industrial Marketing Management.

Roman, S., \& Ruiz, S. (2003). A comparative analysis of sales training in Europe implications for international sales negotiations. Industrial Marketing Review, 20(3), 304-327.

Rubash, A., Sullivan, R.,\&Herzog, P. (1987, August). The use of an 'expert' to train salespeople. Journal of Personal Selling \& Sales Management, 12, 49-55.

Russ, R., Hair, J., Erffmeyer, R., \& Easterling, D. (1989, Spring). Usage and perceived effectiveness of high-tech approaches to sales training. Journal of Personal Selling \& Sales Management, 46-54.

Sánchez-Fernández, R., \& Iniesta-Bonillo, M. Á. (2007). The concept of perceived value: a systematic review of the research. Marketing Theory, 7(4), 427-451.

Singh, J. (1998). Striking a balance in boundary-spanning positions: an investigation of some unconventional influences of role stressors and job characteristics on job outcomes of salespeople. Journal of Marketing, 62, 69-86. 
Spiro R.L., \& Weitz, B. A. (1990). Adaptive selling: conceptualization, measurement, and nomological validity. Journal of Marketing Research, 27 (February), 61-69.

Sonnentag, S. (2003). Recovery, work engagement, and proactive behavior: a new look at the interface between non-work and work. Journal of Applied Psychology, 88(3), 518-528.

Stephenson, R. P., Cron, W. L., \& Frazier, G. L. (1979). Delegating pricing authority to the salesforce: the effects on sales and profit performance. Journal of Marketing,43 (Spring).

Sujan, H., Sujan, M., \& Bettman, J.R. (1988). Knowledge structure differences between more effective and less effective salespeople. Journal of Marketing Research, 25, 81-86.

, Weitz, B.A., and Kumar, N (1994). Learning orientation, working smart, and effective selling. Journal of Marketing, 58 (July), 39-52.

Tellis, G. J. (1986). Beyond the many faces of price: an integration of pricing strategies. The Journal of Marketing, 146-160.

Walker, Orville C. Jr., Gilbert A. Churchill Jr., \& Ford, N. M. (1977). Motivation and performance in industrial selling: present knowledge and needed research. Journal of Marketing Research, 14 (May), 156-168.

Wang, G., \& Netemyer, R. G. (2002). The effects of job autonomy, customer demandingness, and trait competitiveness on salesperson learning, self-efficacy, and performance. Journal of the Academy of Marketing Science, 30(3), 217-228.

Weiss, H.M. (1990). Learning theory and industrial and organizational psychology, in Handbook of Industrial and Organizational Psychology (2nd ed., Vol. 2), M. Dunnette \& L.M. Hough, eds. Palo Alto, CA: Consulting Psychological Press, 171-221.

Weitz, B.A., \& Bradford, K.D. (1999). Personal selling and sales management: a relationship marketing perspective. Journal of the Academy of Marketing Science, 27 (2), 241-254.

McGraw-Hill.

Castleberry, S., \& Tanner, J (2001) Selling: Building Partnerships. New York:

Table 1: Types of sales force training

\begin{tabular}{|l|l|l|l|}
\hline Studies & Focus & Findings & $\begin{array}{l}\text { Learning } \\
\text { Type }\end{array}$ \\
\hline Finn (1984) & $\begin{array}{l}\text { A layered sales } \\
\text { training program }\end{array}$ & $\begin{array}{l}\text { New skills programs which are offered to } \\
\text { sales managers first followed by their } \\
\text { salespeople. }\end{array}$ & VL \\
\hline $\begin{array}{l}\text { Robinson } \\
(1987)\end{array}$ & Role playing & $\begin{array}{l}\text { This paper puts forward role playing and } \\
\text { examples of sales scripts which are } \\
\text { offered. }\end{array}$ & VL \\
\hline Kaminski and & The Fog Index & This index allows firms to verify whether & VL \\
\hline
\end{tabular}




\begin{tabular}{|c|c|c|c|}
\hline $\begin{array}{l}\text { Clark } \\
(1987)\end{array}$ & & $\begin{array}{l}\text { their materials are } \\
\text { appropriate for the educational level of } \\
\text { their salespeople. It also assesses the } \\
\text { readability of reading materials was } \\
\text { introduced and used } \\
\text { with four organization's training manuals. }\end{array}$ & \\
\hline $\begin{array}{l}\text { Rubash et al. } \\
\text { (1987) }\end{array}$ & An expert system & $\begin{array}{l}\text { The computer based system and steps for } \\
\text { applying it to sales training were } \\
\text { discussed. }\end{array}$ & VL \\
\hline $\begin{array}{l}\text { Russ et al. } \\
\text { (1989) }\end{array}$ & $\begin{array}{l}\text { Tech. based sales } \\
\text { training }\end{array}$ & $\begin{array}{l}\text { Microcomputers and interactive video } \\
\text { materials were discussed along with their } \\
\text { perceived effectiveness in achieving sales } \\
\text { training objectives. }\end{array}$ & VL \\
\hline $\begin{array}{l}\text { Martin and } \\
\text { Collins (1991) }\end{array}$ & $\begin{array}{l}\text { Video enabled } \\
\text { sales training }\end{array}$ & $\begin{array}{l}\text { This sales training system used } \\
\text { BellSouth's sales training system for } \\
\text { discussing applications and benefits of } \\
\text { video technology. }\end{array}$ & VL \\
\hline $\begin{array}{l}\text { Honeycutt, } \\
\text { McCarty et al. } \\
(1993)\end{array}$ & $\begin{array}{l}\text { Video enabled } \\
\text { sales training }\end{array}$ & $\begin{array}{l}\text { Sales training effectiveness at Motorola } \\
\text { using video materials. }\end{array}$ & VL \\
\hline $\begin{array}{l}\text { Honeycutt et } \\
\text { al. (1994) }\end{array}$ & Role Playing & $\begin{array}{l}\text { Role playing by sales managers and sales } \\
\text { trainers in the sales training process in } \\
\text { order to improve responsibilities, } \\
\text { communication } \\
\text { and coordination. }\end{array}$ & VL \\
\hline $\begin{array}{l}\text { Erffmeyer and } \\
\text { Johnson } \\
(1997)\end{array}$ & Distance learning & $\begin{array}{l}\text { Distance learning was not considered to } \\
\text { be effective in this study. }\end{array}$ & VL \\
\hline $\begin{array}{l}\text { Honeycutt, } \\
\text { Ford, Lupton, } \\
\text { and Flaherty } \\
\text { (1999) }\end{array}$ & $\begin{array}{l}\text { Sales training of } \\
\text { global and } \\
\text { domestic } \\
\text { organization. }\end{array}$ & $\begin{array}{l}\text { A comparison between global and } \\
\text { domestic organizations regarding sales } \\
\text { training's content and the amount of time } \\
\text { spent on training. }\end{array}$ & VL \\
\hline $\begin{array}{l}\text { Wang and } \\
\text { Netemeyer } \\
(2002)\end{array}$ & $\begin{array}{l}\text { Social cognitive } \\
\text { theory }\end{array}$ & $\begin{array}{l}\text { This study reports that salesperson's } \\
\text { learning effort affects self-efficacy which } \\
\text { positively affects performance. } \\
\text { Furthermore, perceived job autonomy and } \\
\text { customer demandingness also affect } \\
\text { salesperson learning effort and self- } \\
\text { efficacy. }\end{array}$ & $V L+E L$ \\
\hline $\begin{array}{l}\text { Roman and } \\
\text { Ruiz (2003) }\end{array}$ & $\begin{array}{l}\text { Regional } \\
\text { differences in } \\
\text { sales training } \\
\text { program }\end{array}$ & $\begin{array}{l}\text { A comparison of sales training was } \\
\text { conducted between Northern and Southern } \\
\text { European firms on company policy, } \\
\text { product knowledge, team work, trust and } \\
\text { relationship issues. }\end{array}$ & VL \\
\hline $\begin{array}{l}\text { Leach, Liu, } \\
\text { and Johnston }\end{array}$ & $\begin{array}{l}\text { Self-regulation } \\
\text { skills }\end{array}$ & $\begin{array}{l}\text { Self-regulatory training to improve time } \\
\text { management and goal setting. }\end{array}$ & VL \\
\hline
\end{tabular}




\begin{tabular}{|l|l|l|l|}
\hline$(2005)$ & & & \\
\hline $\begin{array}{l}\text { Franke and } \\
\text { Park (2006) }\end{array}$ & $\begin{array}{l}\text { Adaptive selling } \\
\text { behaviour and } \\
\text { customer } \\
\text { orientation }\end{array}$ & $\begin{array}{l}\text { Both adaptive selling behaviour and } \\
\text { customer orientation improve satisfaction } \\
\text { and job performance. }\end{array}$ & EL \\
\hline $\begin{array}{l}\text { Ricks et al. } \\
(2008)\end{array}$ & $\begin{array}{l}\text { Case study on } \\
\text { trainer roles, } \\
\text { competencies, } \\
\text { skills, and } \\
\text { behaviors }\end{array}$ & $\begin{array}{l}\text { Limited needs assessment, } \\
\text { lack of training objectives, no alignment } \\
\text { between training objectives and corporate } \\
\text { goals, and sales training content, are all } \\
\text { potential factors that } \\
\text { can influence the effectiveness of training } \\
\text { programs. }\end{array}$ & VL + EL \\
\hline
\end{tabular}

*Type of study: $\mathrm{VL}=$ Vicarious learning , E= Enactive learning

Table 2: Types of sales skills

\begin{tabular}{|l|l|l|l|}
\hline Studies & Focus & Definitions & Examples \\
\hline $\begin{array}{l}\text { Ford et al. } \\
(1987)\end{array}$ & $\begin{array}{l}\text { Interpersonal } \\
\text { Skills }\end{array}$ & $\begin{array}{l}\text { An ability to understand, persuade } \\
\text { and getting along with customers }\end{array}$ & $\begin{array}{l}\text { Communication and } \\
\text { Presentation Skills }\end{array}$ \\
\hline $\begin{array}{l}\text { Weitz et al. } \\
\text { p. } 1986,\end{array}$ & Adaptiveness & $\begin{array}{l}\text { An ability to adjust behaviors } \\
\text { during an exchange process based } \\
\text { on information }\end{array}$ & $\begin{array}{l}\text { Ability to Modify Sales } \\
\text { Presentations } \\
\text { Adaptive Selling }\end{array}$ \\
\hline $\begin{array}{l}\text { Leong et al. } \\
(1989)\end{array}$ & $\begin{array}{l}\text { Selling related } \\
\text { knowledge }\end{array}$ & $\begin{array}{l}\text { It refers to the degree of } \\
\text { knowledge that a salesperson } \\
\text { needs to fix sales situations, }\end{array}$ & $\begin{array}{l}\text { Customer Knowledge } \\
\text { Product / Technical } \\
\text { Knowledge }\end{array}$ \\
\hline
\end{tabular}




\begin{tabular}{|c|c|c|c|}
\hline & & $\begin{array}{l}\text { identify different types of } \\
\text { prospects, and select customized } \\
\text { sales strategies for clients. }\end{array}$ & \\
\hline $\begin{array}{l}\text { Sujan et al. } \\
(1994)\end{array}$ & $\begin{array}{l}\text { Goal } \\
\text { Orientation }\end{array}$ & $\begin{array}{l}\text { It refers to the specific goals that } \\
\text { salespeople pursue in achievement } \\
\text { situations }\end{array}$ & $\begin{array}{l}\text { Performance Goal, } \\
\text { Orientation, Learning } \\
\text { Goal Orientation }\end{array}$ \\
\hline $\begin{array}{l}\text { Sonnentag } \\
\text { (2003) }\end{array}$ & $\begin{array}{l}\text { Work } \\
\text { engagement }\end{array}$ & $\begin{array}{l}\text { It refers to the extent of persistent } \\
\text { positive affective-motivational } \\
\text { state of fulfillment. }\end{array}$ & $\begin{array}{l}\text { Enthusiasm } \\
\text { Citizenship Behaviors }\end{array}$ \\
\hline \multirow[t]{2}{*}{$\begin{array}{l}\text { Ford et al. } \\
\text { (1983) }\end{array}$} & Personal & $\begin{array}{l}\text { It refers to the internal factors of } \\
\text { an individual that might be related } \\
\text { to salespeople's performance but } \\
\text { which are not part of the aptitude, } \\
\text { skill level, motivation and role } \\
\text { perceptions components. }\end{array}$ & Age, sales experience \\
\hline & $\begin{array}{l}\text { Organizational } \\
\text { and } \\
\text { environmental }\end{array}$ & $\begin{array}{l}\text { It refers to the environmental } \\
\text { factors that influence sales } \\
\text { performance. }\end{array}$ & $\begin{array}{l}\text { External (Market } \\
\text { Competition, Prospect } \\
\text { Income), Internal } \\
\text { (Marketing Orientation, } \\
\text { Flexibility), Supervisory } \\
\text { (Positive Feedback } \\
\text { Transformational } \\
\text { Leadership) }\end{array}$ \\
\hline $\begin{array}{l}\text { Walker } \\
(1977), \\
\text { Singh } \\
(1998)\end{array}$ & Role conflict & $\begin{array}{l}\text { It refers to the perceptions of } \\
\text { demands and expectations by role } \\
\text { partners. }\end{array}$ & $\begin{array}{l}\text { Role ambiguity, role } \\
\text { overload }\end{array}$ \\
\hline
\end{tabular}


Table 3

RESULTS FROM THE BAYESIAN LEARNING MODEL

(STANDARD DEVIATION)

\begin{tabular}{|c|c|c|c|c|c|c|}
\hline & Intercept & Salary & Gender & Age & Marital Status & Education \\
\hline Potential Match Skill & $\begin{array}{c}0.65 \\
(0.32)\end{array}$ & $\begin{array}{l}-0.13 \\
(0.28)\end{array}$ & $\begin{array}{l}-0.52 \\
(0.69)\end{array}$ & $\begin{array}{c}0.56 \\
(0.27)\end{array}$ & $\begin{array}{c}0.27 \\
(0.66)\end{array}$ & $\begin{array}{c}1.00 \\
(1.22)\end{array}$ \\
\hline $\begin{array}{l}\text { Learning Variability from } \\
\text { Success(Logged) }\end{array}$ & $\begin{array}{c}5.48 \\
(1.00)\end{array}$ & $\begin{array}{l}-3.38 \\
(0.78)\end{array}$ & $\begin{array}{l}-7.98 \\
(1.44)\end{array}$ & $\begin{array}{c}2.07 \\
(0.45)\end{array}$ & $\begin{array}{l}-0.58 \\
(1.14)\end{array}$ & $\begin{array}{l}-9.65 \\
(2.12)\end{array}$ \\
\hline Learning Variability from & $\begin{array}{c}3.52 \\
(0.31)\end{array}$ & $\begin{array}{l}-1.81 \\
(0.67)\end{array}$ & $\begin{array}{l}-4.65 \\
(0.69)\end{array}$ & $\begin{array}{c}0.66 \\
(0.25)\end{array}$ & $\begin{array}{l}-1.60 \\
(1.01)\end{array}$ & $\begin{array}{l}1.33 \\
(1.11)\end{array}$ \\
\hline Prior Match Skill & $\begin{array}{l}-0.02 \\
(0.21)\end{array}$ & $\begin{array}{c}1.30 \\
(0.30)\end{array}$ & $\begin{array}{c}0.68 \\
(0.54)\end{array}$ & $\begin{array}{l}-0.31 \\
(0.13)\end{array}$ & $\begin{array}{c}0.12 \\
(0.50)\end{array}$ & $\begin{array}{c}0.94 \\
(0.69)\end{array}$ \\
\hline Prior Variance(Logged) & $\begin{array}{l}-0.65 \\
(0.46)\end{array}$ & $\begin{array}{l}-1.02 \\
(0.76)\end{array}$ & $\begin{array}{l}-5.70 \\
(0.50)\end{array}$ & $\begin{array}{c}0.57 \\
(0.22)\end{array}$ & $\begin{array}{l}-1.40 \\
(1.03)\end{array}$ & $\begin{array}{c}0.22 \\
(1.27)\end{array}$ \\
\hline Utility Weight & $\begin{array}{l}0.15 \\
(0.14)\end{array}$ & $\begin{array}{l}-0.18 \\
(0.11)\end{array}$ & $\begin{array}{c}0.04 \\
(0.33)\end{array}$ & $\begin{array}{l}-0.07 \\
(0.07)\end{array}$ & $\begin{array}{c}0.26 \\
(0.25)\end{array}$ & $\begin{array}{l}-1.14 \\
(0.45)\end{array}$ \\
\hline Client Ranking & $\begin{array}{l}0.29 \\
(0.24)\end{array}$ & $\begin{array}{l}-0.18 \\
(0.26)\end{array}$ & $\begin{array}{c}0.24 \\
(0.46)\end{array}$ & $\begin{array}{c}0.02 \\
(0.12)\end{array}$ & $\begin{array}{c}0.46 \\
(0.47)\end{array}$ & $\begin{array}{l}-0.96 \\
(0.71)\end{array}$ \\
\hline Open Days & $\begin{array}{l}-10.02 \\
(0.80)\end{array}$ & $\begin{array}{r}0.49 \\
(0.67)\end{array}$ & $\begin{array}{c}0.27 \\
(1.59)\end{array}$ & $\begin{array}{l}-0.08 \\
(0.38)\end{array}$ & $\begin{array}{l}-0.15 \\
(1.58)\end{array}$ & $\begin{array}{c}0.07 \\
(2.17)\end{array}$ \\
\hline Case size & $\begin{array}{l}-0.41 \\
(0.15)\end{array}$ & $\begin{array}{c}0.27 \\
(0.17)\end{array}$ & $\begin{array}{l}-0.03 \\
(0.34)\end{array}$ & $\begin{array}{l}-0.16 \\
(0.08)\end{array}$ & $\begin{array}{c}0.09 \\
(0.34)\end{array}$ & $\begin{array}{c}0.19 \\
(0.69)\end{array}$ \\
\hline \multicolumn{7}{|l|}{ Outside good } \\
\hline Big Competitor & $\begin{array}{l}-0.35 \\
(0.13)\end{array}$ & $\begin{array}{l}-0.06 \\
(0.13)\end{array}$ & $\begin{array}{l}-0.66 \\
(0.33)\end{array}$ & $\begin{array}{c}0.10 \\
(0.07)\end{array}$ & $\begin{array}{l}-0.19 \\
(0.28)\end{array}$ & $\begin{array}{l}-0.52 \\
(0.43)\end{array}$ \\
\hline Competition & $\begin{array}{c}4.51 \\
(0.99)\end{array}$ & $\begin{array}{c}0.47 \\
(0.32)\end{array}$ & $\begin{array}{c}3.50 \\
(1.53)\end{array}$ & $\begin{array}{l}-0.98 \\
(0.47)\end{array}$ & $\begin{array}{l}-0.90 \\
(1.72)\end{array}$ & $\begin{array}{l}-4.80 \\
(2.04)\end{array}$ \\
\hline
\end{tabular}


Figure 1

SALESPEOPLE'S LEARNING BY DOING PROCESS.

When the salesperson first enters the company

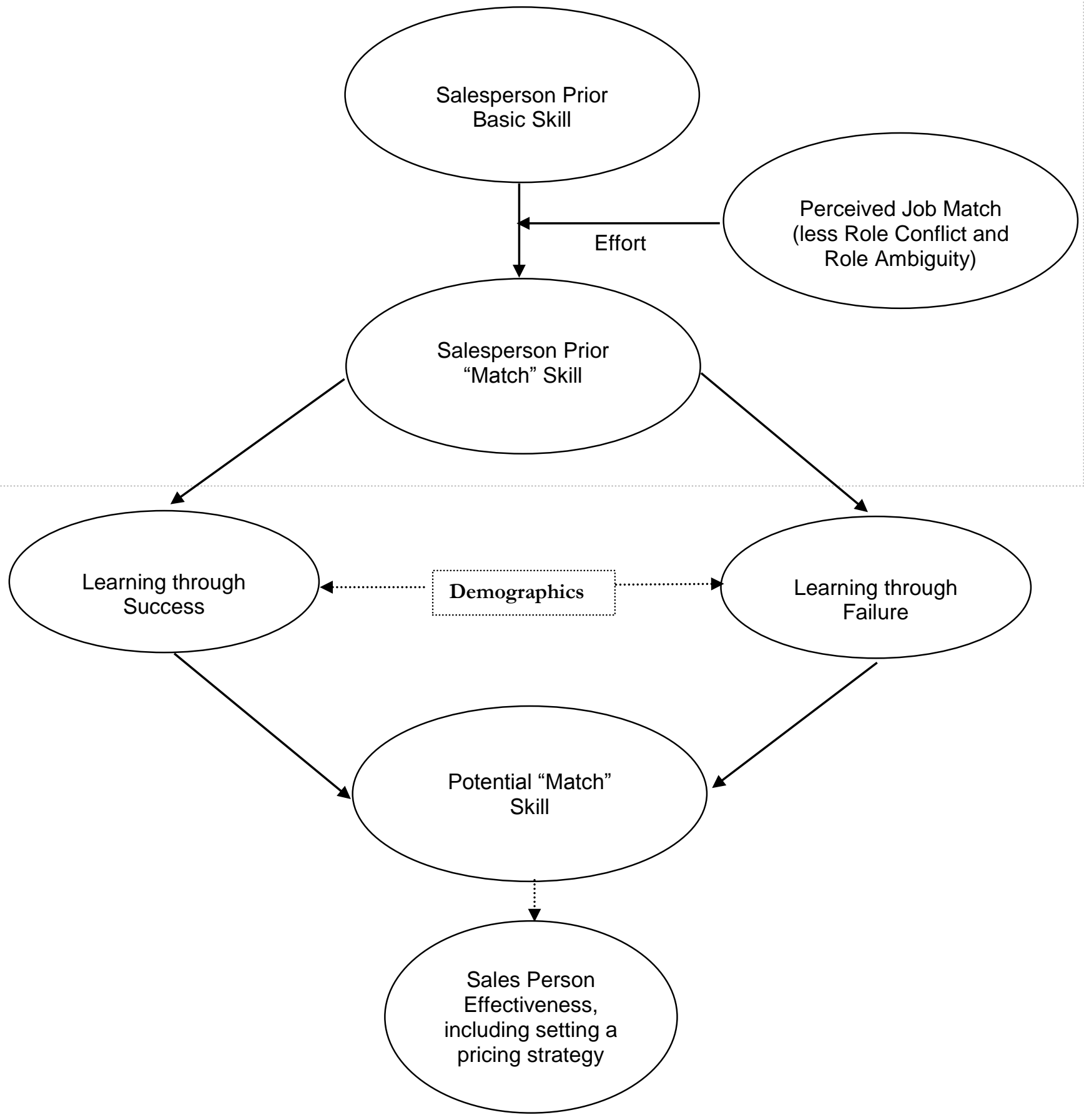


